\title{
Nutritional Evaluation of Non-Conventional Vegetables in Brazil
}

\author{
LUIS FELIPE LIMA E SILVA ${ }^{1}$, DOUGLAS C. DE SOUZA ${ }^{1}$, LUCIANE V. RESENDE ${ }^{1}$, RITA DE \\ CÁSSIA M.R. NASSUR ${ }^{2}$, CAROLINA Q. SAMARTINI ${ }^{2}$ and WILSON M. GONÇALVES ${ }^{2}$ \\ ${ }^{1}$ Departamento de Agricultura, Universidade Federal de Lavras/UFLA, Campus \\ Universitário, s/n, Caixa Postal 3037, 37200-000 Lavras, MG, Brazil \\ ${ }^{2}$ Departamento de Tecnologia e Ciências Sociais, Universidade do Estado da Bahia/UNEB, \\ Campus III, Rua Edgard Chastinet, s/n, São Geraldo, 48905-680 Juazeiro, BA, Brazil \\ Manuscript received on July 03, 2017; accepted for publication on December 18, 2017
}

\begin{abstract}
The objective of this study was to characterize the nutritional compounds of interest present in vegetables known as non-conventional, in Brazil. The following evaluations were carried out: antioxidant activity, phenolic compounds, vitamin $\mathrm{C}$, calories, carbohydrates, humidity, lipids, proteins, fiber, acidity and quantification of minerals ( $\mathrm{P}, \mathrm{K}, \mathrm{Ca}, \mathrm{Mg}, \mathrm{S}, \mathrm{Cu}, \mathrm{Fe}, \mathrm{Mn}, \mathrm{Zn}$ and B). The species studied were Amaranthus hybridus L., Amaranthus viridis L., Basella alba L., Eryngium campestre L., Hibiscus sabdariffa L., Lactuca canadensis L., Rumex acetosa L., Stachys byzantina K. Koch, Tropaeolum majus L. and Xanthosoma sagittifolium L. Representative samples of plant structures of interest were harvested from each species suitable for human consumption such as leaves, flowers and flower buds. The results were submitted to multivariate analysis - principal components analysis (PCA). All the species present nutritional compounds of interest in different levels among the evaluated structures.
\end{abstract}

Key words: bioactive compounds, food safety, nutraceutical food, traditional vegetables.

\section{INTRODUCTION}

In the past, some native or introduced vegetables were widely consumed by the population, in Brazil. However, due to the great supply of the so-called genetically improved modern vegetables - in a way, more attractive, mainly because they have already been very well inserted in the national and international market of seed production - many of these vegetables are no longer consumed. This happened due to the lack of supply in the market and, thus, these vegetables became unknown

Correspondence to: Douglas Correa de Souza

E-mail: douglascorrea@ymail.com to the new generations. However, some of these species are still consumed by rural, indigenous and quilombola (the "quilombos" were communities formed during the colonial period of Brazil by runaway slaves. Even today, they remain as independent communities, preserving the cultural heritage of their ancestors) populations being termed as non-conventional vegetables.

These vegetables are distributed in several botanical families and they are being redeemed and deposited in germplasm collections of public institutions with the aim of preserving biodiversity and studying the probable pharmacological 
potential and even the anti-nutritional principles of these species.

There are already reports of the nutritional potential of some species. The grain amaranths (Amaranthus spp.), for instance, presents calcium, magnesium, nitrogen, iron and phosphorus (Souza et al. 1999, Costa et al. 2008); the malabar spinach (Basella alba L.) presents varied rates of carotenoids and vitamins A and C (Brasil 2002, Batista et al. 2008, Oliveira et al. 2013); the roselle (H. sabdariffa L.) is rich in minerals, vitamins A and B1 and fibers (Brasil 2013); the sorrel (Rumex acetosa L.) presents nutritional and pharmacological potential in its constitution from minerals, antioxidants, vitamins, fibers, nutrients and proteins (Silva et al. 2013); the lamb's-ear (Stachys byzantina K. Koch) presents high levels of vitamin C, vitamin $\mathrm{K}$, carbohydrates and antioxidant potential besides a wide range of bioactive compounds presented by species of the genus Stachys, widely used in the pharmacological industry (Asnaashari et al. 2010); the garden nasturtium (T. majus L.) presents, in its composition, vitamin $\mathrm{C}$, minerals, carbohydrates, antioxidant power, essential oils besides potential pharmacological use because it presents a large spectrum of bioactive compounds (Niizu and Rodriguez-Amaya 2005, Embrapa 2006, Garzón and Wrolstad 2009, Mlcek and Rop 2011) and the arrowleaf elephant ear (X. sagitifolium L.) presents significant levels of carbohydrates, proteins, iron, minerals and vitamins A and C ( $\mathrm{Lu}$ et al. 2005, Rodríguez et al. 2006, Brasil 2010, Ndabikunze et al. 2011). However, it is known that the levels of these compounds vary widely according to environmental, genetic and management factors (Melo et al. 2006, Costa et al. 2008, Arbos et al. 2010).

After the confirmation of its nutritional potential, the consumption of these nonconventional vegetables could be presented as an excellent option as a source of nutritional compounds especially for populations with lower purchasing power, however, studies proving its nutritional properties are still incipient. It is known that some of these species may also exhibit antinutritional compounds such as protein inhibitors, calcium oxalates, tannins, nitrates, among others (Van Velzen et al. 2008, De Jesus Benevides et al. 2011).

Aiming to obtain a more in-depth knowledge about the potential of non-conventional vegetables, the objective of this study was to evaluate the nutritional compounds of interest in 10 species of non-conventional vegetables in Brazil.

\section{MATERIALS AND METHODS}

The analyzed species were Amaranthus hybridus L. (green amaranth), Amaranthus viridis L. (slender amaranth), Basella alba L. (malabar spinach), Eryngium campestre L. (field eryngo), Hibiscus sabdariffa L. (roselle), Lactuca canadensis L. (canada lettuce), Rumex acetosa L. (sorrel, two different cultivated varieties), Stachys byzantina K. Koch (lamb's ear), Tropaeolum majus L. (garden nasturtium) and Xanthosoma sagittifolium L. (arrowleaf elephant ear).

The samples were collected from the Germplasm Collection of Non-Conventional Vegetables located in the experimental garden of the Federal University of Lavras, Minas Gerais, Brazil, latitude $21^{\circ} 14^{\prime} \mathrm{S}$, longitude $45^{\circ} 00^{\prime} \mathrm{W}$ and average altitude of 919 meters $(3011,81 \mathrm{ft})$. The climate of the region is classified as humid temperate, with a hot summer and a dry winter, being, therefore, of the type Cwa in the Köppen classification. The species studied included different botanical families, growth habits and life cycle, as well as the potential for food use. They comprise varieties obtained from selections made by farmers, variant forms of cultivated species and wild species of the genera of interest for the national olericulture. The plant parts used for analysis were those usually 
consumed as food in each species studied, and could be the leaves, the flowers or the floral buds.

In the field, about 60 plants of each species were conducted in a randomized block design with four replicates. Then, a sample was taken from the central - viable - plants of each block, just considering the internal plants of the block. The plants were conducted in a flowerbed in the field, they were irrigated by drip irrigation and the soil was fertilized with $150 \mathrm{~kg} \cdot \mathrm{ha}^{-1} \mathrm{~N}, 60 \mathrm{~kg} \cdot \mathrm{ha}^{-1}$ of $\mathrm{K}_{2} \mathrm{O}$ and $100 \mathrm{~kg} \cdot \mathrm{ha}^{-1}$ of $\mathrm{P}_{2} \mathrm{O}_{5}$ given the good availability of $\mathrm{P}$ and $\mathrm{K}$ in the experimental soil, obtained by previous chemical analysis.

The samples were collected from the parts of each plant, at a complete stage of development in Amaranthus spp., B. alba, E. campestre, Lactuca canadensis L., Rumex acetosa L., Stachys byzantina K. Koch, Tropaeolum majus L. and Xanthosoma sagittifolium. The floral samples were collected after the anthesis in the species Tropaeolum majus L. and before the anthesis in the species Hibiscus sabdariffa $\mathrm{L}$. The statistical design was completely randomized, with twelve treatments in triplicate and each treatment corresponding to a food structure of one species, at around $200 \mathrm{~g}$ per repetition.

The samples were sanitized and part used for the following evaluations: antioxidant activity according to Brand-Williams et al. (1995) and adapted by Rufino et al. (2007); phenolic compounds according to the colorimetric method developed by Singleton and Rossi (1965); vitamin C according to Strohecker and Henning (1967); total pectin according to McCready and McComb (1952); total carotenoids in the flowers of $H$. sabdariffa and T. majus according to RodriguezAmaya et al. (1976); anthocyanins according to Giusti and Wrolstad (2001); centesimal composition according to the Horowitz (2016); calorific value according to Osborne and Voogt (1978); acidity, lipids and humidity according to the Horowitz (2016); fiber according to Kjeldahl (1983) adapted by the Horowitz (2016) and nitrate according to
Cataldo et al. (1975). Another part of the samples was used for the quantification of the $\mathrm{P}, \mathrm{K}, \mathrm{Ca}$, $\mathrm{Mg}, \mathrm{S}, \mathrm{Cu}, \mathrm{Fe}, \mathrm{Mn}, \mathrm{Zn}$ and $\mathrm{B}$ minerals where the preparation of the samples and the determination of the nutrients followed the methodology proposed by Silva (2009).

The results were then normalized and submitted for an analysis of the main components using the Chemoface software (version 1.4). The analysis of the main components is a multivariate statistical tool whose principle is to study the behavior of many variables at the same time, reducing these variables by means of mathematical criteria, allowing visualizing in two-dimensional graphs only the most representative main components of the data sets (De Souza Pereira et al. 2014). The data was normalized and, then, decomposed into a covariance matrix. The results of the PCA were generated according to component scores. At the end, it was possible to load the biplot graphics with the two main components.

The main components present in the following datasets were analyzed: 1 - Antioxidant activity, phenolic compounds and Vitamin C, 2 - Nitrate, carbohydrates, lipids, proteins and crude fiber, 3 - Macronutrients (P, K, Ca, Mg and S) and 4 Micronutrients $(\mathrm{Cu}, \mathrm{Fe}, \mathrm{Mn}, \mathrm{Zn}$ and $\mathrm{B})$ with the aim of characterizing the nutritional constitution of the species as well as to verify which components stood out between the constitution of each structure and species evaluated. The results of the statistical analyzes were expressed in "biplot" type charts, in order to determine possible trends and patterns in the results.

\section{RESULTS}

In general, the dry weight of all the structures presented in their constitution levels of vitamin $\mathrm{C}$, ranging from a minimum of $69.94 \mathrm{mg} .100 \mathrm{~g}^{-1}$ on H. sabdariffa's floral bud to a maximum of 195.58 mg. $100 \mathrm{~g}^{-1}$ in X. sagittifolium's leaves. The phenolic 
levels also varied among the studied species with the lowest level being observed on $R$. acetosa ${ }^{1}$ $\left(8.74 \mathrm{mg} .100 \mathrm{~g}^{-1}\right)$ and the highest on $S$. byzantina (209.40 mg. $\left.100 \mathrm{~g}^{-1}\right)$.

Although all the non-conventional vegetables evaluated showed high vitamin C levels, the analysis of the main components, between the variation of antioxidant activity and the vitamin $\mathrm{C}$ and phenolic contents, allowed the discrimination of the species between these levels, being that the two main components represented in the biplot graph (Fig. 1) represented $98 \%$ of all the observed variance, which proves the efficiency of this technique in the discrimination of these treatments. The treatments were well distributed in the quadrants of the graph, mainly according to their similarities between vitamin $\mathrm{C}$ and phenolic levels.

The species T. majus (leaf) and A. hybridus stood out mainly because they presented the highest rates of antioxidant activity and were also, among the highest values for the constitution in total phenols and vitamin C. The species $S$. byzantina presented the highest observed levels of total phenols as well as low levels of vitamin C, which has characterized it in presenting average capacity of free radical scavenging. The species B. alba, A. viridis, X. sagittifolium and T. majus (flower) presented high levels of vitamin $\mathrm{C}$ and average levels of phenols and antioxidant activity with the exception of T. majus flower that presented a high level of antioxidant activity (68.32\%) when compared to other observed results. Among the other species evaluated, L. canadensis, R. acetosa ${ }^{1}$, $R$. acetosa $a^{2}, E$. campestre and $H$. sabdariffa were the ones to present levels of vitamin $\mathrm{C}$, phenols and antioxidant activity ranging from low to average.

Indeed the high capacity of free radical scavenging in the leaves of T. majus can be linked to both the content of phenols $\left(167.84 \mathrm{mg} .100 \mathrm{~g}^{-1}\right)$ as well as the level of vitamin C (188.55 mg.100g $\left.{ }^{-1}\right)$. Meanwhile, the species $S$. byzantina presented a high level of phenols $\left(209.40 \mathrm{mg} .100 \mathrm{~g}^{-1}\right)$ but a free radical scavenging capacity of only $46.51 \%$ showing that, in this species, the phenols detected by the analysis performed are not efficient as antioxidants. Another important fact is the difference in the capacity of free radical scavenging observed between the two morphological types of $R$. acetosa, where $R$. acetos $a^{2}$ presented this capacity about 4 times higher than $R$. acetos $a^{1}$.

The floral bud of $H$. Sabdariffa presented pectin and anthocyanins in their constitution in values of $1450 \mathrm{mg} \cdot 100 \mathrm{~g}^{-1}$ and $954.62 \mathrm{mg} . \mathrm{L}^{-1}$ respectively. Despite high levels of anthocyanins, the floral buds of $H$. sabdariffa showed a low free radical scavenging capacity, about $20 \%$, showing that in this species these pigments are not efficient as antioxidants.

Carotenoids were observed in the flowers of H. sabdariffa and T. majus at levels of 221.59 mg. $100 \mathrm{~g}^{-1}$ and $711.84 \mathrm{mg} .100 \mathrm{~g}^{-1}$ respectively.

All structures of the evaluated species presented nitrate content in their constitutions. The species A. hybridus and T. majus presented in their leaves the highest levels of this compound, being $169 \mathrm{mg} .100 \mathrm{~g}^{-1}$ and $186 \mathrm{mg} .100 \mathrm{~g}^{-1}$ respectively. For the other evaluated structures, the nitrate level ranged from a minimum average of $30 \mathrm{mg} \cdot 100 \mathrm{~g}^{-1}$ for the leaves of E. campestre and R. acetosa ${ }^{1,2}$, with an average content of $128 \mathrm{mg} .100 \mathrm{~g}^{-1}$ observed in the leaves of $A$. viridis and $X$. sagittifolium.

All the structures of the evaluated species presented humidity levels above $70 \%$ and below $93 \%$, with higher values in $R$. acetosa, B. alba and T. majus (flowers) species (91\% on average). Therefore, taking into account that water is the main component of the evaluated structures, it was analyzed the main components considering carbohydrates, lipids, proteins, fiber and nitrate as variables(Fig. 2), in order to discriminate the species, according to possible patterns in the contents of these compounds present in their structures, besides the water. The two main components represented in the biplot graph (Fig. 2) explained $73 \%$ of all the 


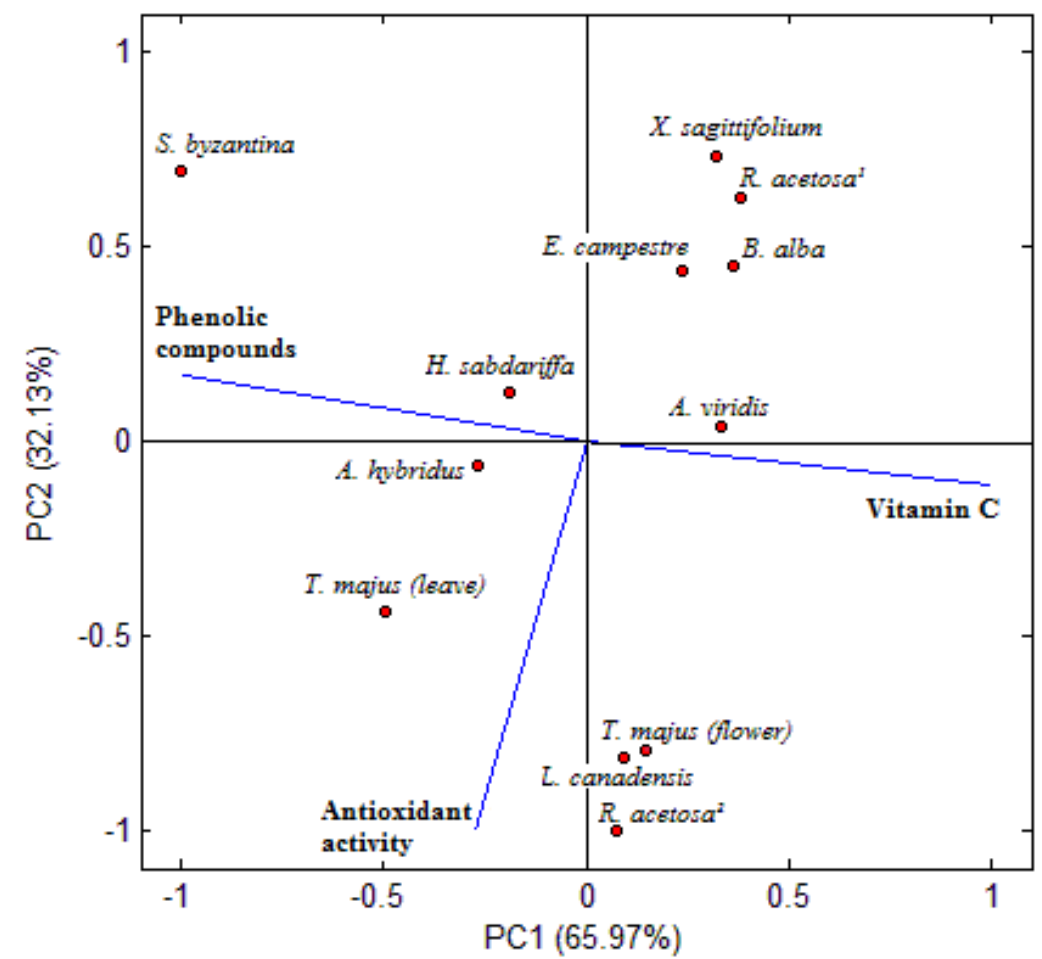

Figure 1 - Analysis of the main components related to the observed results for antioxidant activity, vitamin $\mathrm{C}$ and phenolic compounds.

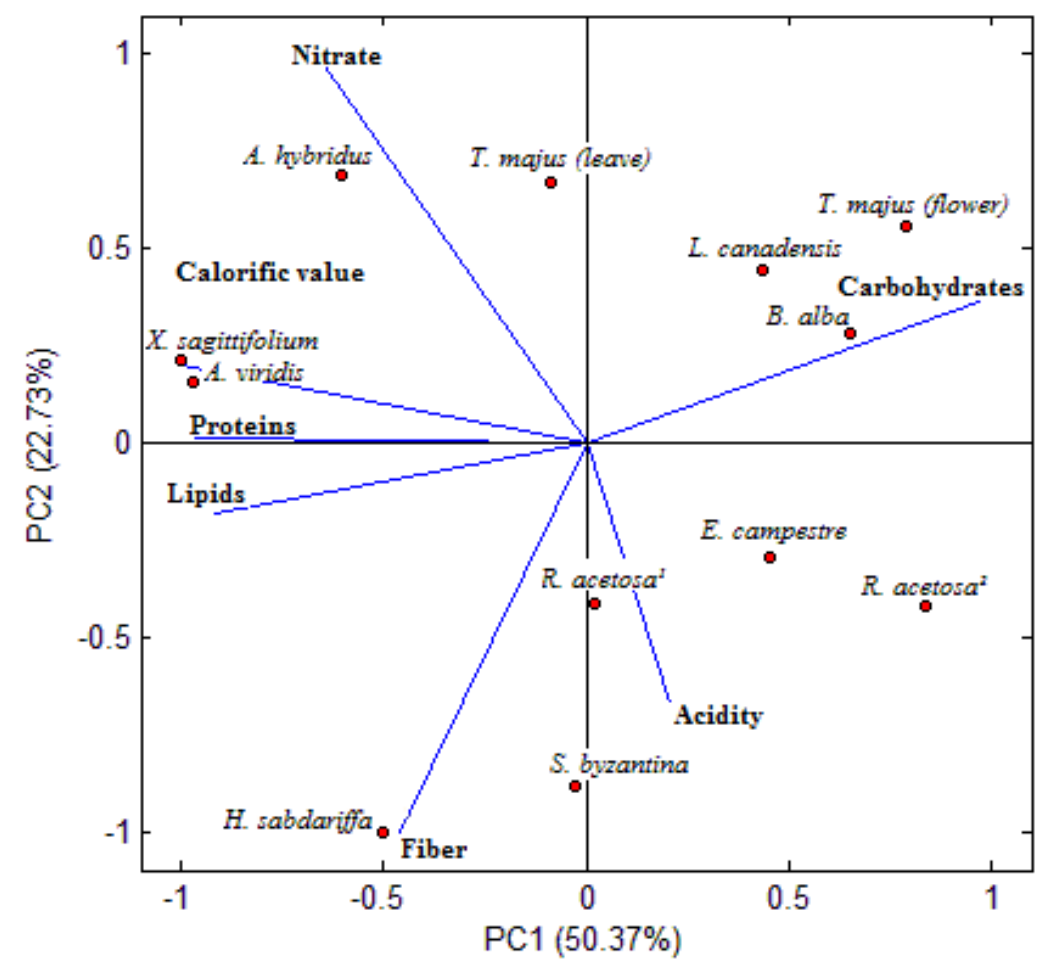

Figure 2 - Analysis of the main components related to the observed results for the levels of carbohydrate, acidity, fiber, lipids, proteins, calorific value and nitrate. 
observed variance, which confirms the efficiency of this technique in the discrimination of these treatments. According to the nutritional similarities between the carbohydrate, lipid, protein, fiber and nitrate levels, the treatments were well distributed in the quadrants of the graph.

The species $A$. viridis, $S$. byzantina, $H$. sabdariffa, A. hybridus and X. sagittifolium stood out because they presented the highest nutritional levels observed in these evaluations. T. majus stood out because it presented the highest level of carbohydrates (8330 mg.100g $\mathrm{g}^{-1}$ ) and lipids (1520 $\left.\mathrm{mg} .100 \mathrm{~g}^{-1}\right)$ and a high level of proteins $(3320 \mathrm{mg}$. $\left.100 \mathrm{~g}^{-1}\right)$. Consequently, the leaves of this species had the highest energy level, in a total of 60.32 $\mathrm{kcal} .100 \mathrm{~g}^{-1}$. On the other hand, the flower, with greater commercial appeal, presented significantly lower values for these variables compared to the leaves and consequently presented lower calorific value. It is interesting to note also the variation in the content of these compounds between the two morphological types of $R$. acetosa, where $R$. acetosa ${ }^{2}$ presented $32.7 \%$ and $25 \%$ more carbohydrates and lipids respectively, a characteristic already observed for antioxidant activity. Among the remaining species, E. campestre, L. canadensis and T. majus (flower), presented high levels of carbohydrates and intermediate values in the other evaluations, while the species $R$. acetos $a^{1,2}$ and $B$. alba presented the lowest values observed among these nutrients.

In the acidity level, the flowers of $H$. sabdariffa stood out $\left(2.27 \mathrm{mg} .100 \mathrm{~g}^{-1}\right)$, along the two morphological types of $R$. acetosa, which presented $1.72 \mathrm{mg} .100 \mathrm{~g}^{-1}$ and $1.42 \mathrm{mg} .100 \mathrm{~g}^{-1}$ for $R$. acetos $a^{2}$ and $R$. acetosa $a^{1}$ respectively.

The highest levels of fiber were observed in $S$. byzantina leaves and in the floral buds of $H$. sabdariffa in values of $4570 \mathrm{mg} \cdot 100 \mathrm{~g}^{-1}$ and 3950 $\mathrm{mg} .100 \mathrm{~g}^{-1}$ respectively. A low level of fiber was observed in T. majus flowers and in $B$. alba leaves within an average value of $640 \mathrm{mg} .100 \mathrm{~g}^{-1}$, while intermediate levels were observed for the other structures of the evaluated species.

The structures of the evaluated species presented varied levels for the protein constitution, oscillating from a minimum average of 1320 mg. $100 \mathrm{~g}^{-1}$ in L. canadensis, E. campestre and Rumex acetos $a^{2}$ leaves to the maximum of $5790 \mathrm{mg} \cdot 100 \mathrm{~g}^{-1}$ in $A$. viridis leaves. The other species presented an intermediate constitution within an average of $3440 \mathrm{mg} .100 \mathrm{~g}^{-1}$ presented by T. majus, S. byzantina and $X$. sagittifolium leaves and by the floral buds of $H$. sabdariffa. Further studies are required as regards the digestibility and bioavailability of these proteins in the human organism or animal organism, depending on each use and purpose.

The analysis of the main components among the mineral constituents allowed discriminating the species according to these elements (Figs. 3 and 4). In relation to the nutrients $\mathrm{P}, \mathrm{K}, \mathrm{Ca}, \mathrm{Mg}$ and $\mathrm{S}$, the main components accounted $77 \%$ of the total data variance; while for $\mathrm{Cu}, \mathrm{Fe}, \mathrm{Mn}, \mathrm{Zn}$ and B nutrients, the major components accounted $88 \%$ of the total variance observed. These values prove the efficiency of this technique in discriminating the treatments used in each of these cases, since the treatments were well distributed in the quadrants of both graphs.

Among the nutrients $\mathrm{P}, \mathrm{K}, \mathrm{Ca}, \mathrm{Mg}$ and $\mathrm{S}$, the species $A$. viridis, $A$. hybridus, $X$. sagittifolium and $B$. alba stood out because they contained the highest levels, mainly related to the $\mathrm{K}$ component. Among these species, A. viridis was noted for having the highest levels observed in almost all evaluations, whereas $X$. sagittifolium stood out because it presented the highest level of P. In these same parameters, T. majus (flower and leaves) and E. campestre species also stood out because they presented high levels for a great part of the evaluated macronutrients, and the highest observed values for the levels of $\mathrm{S}$ and $\mathrm{P}$. The species $T$. majus (flower and leaf) presented a prominent place, because, besides presenting the highest 


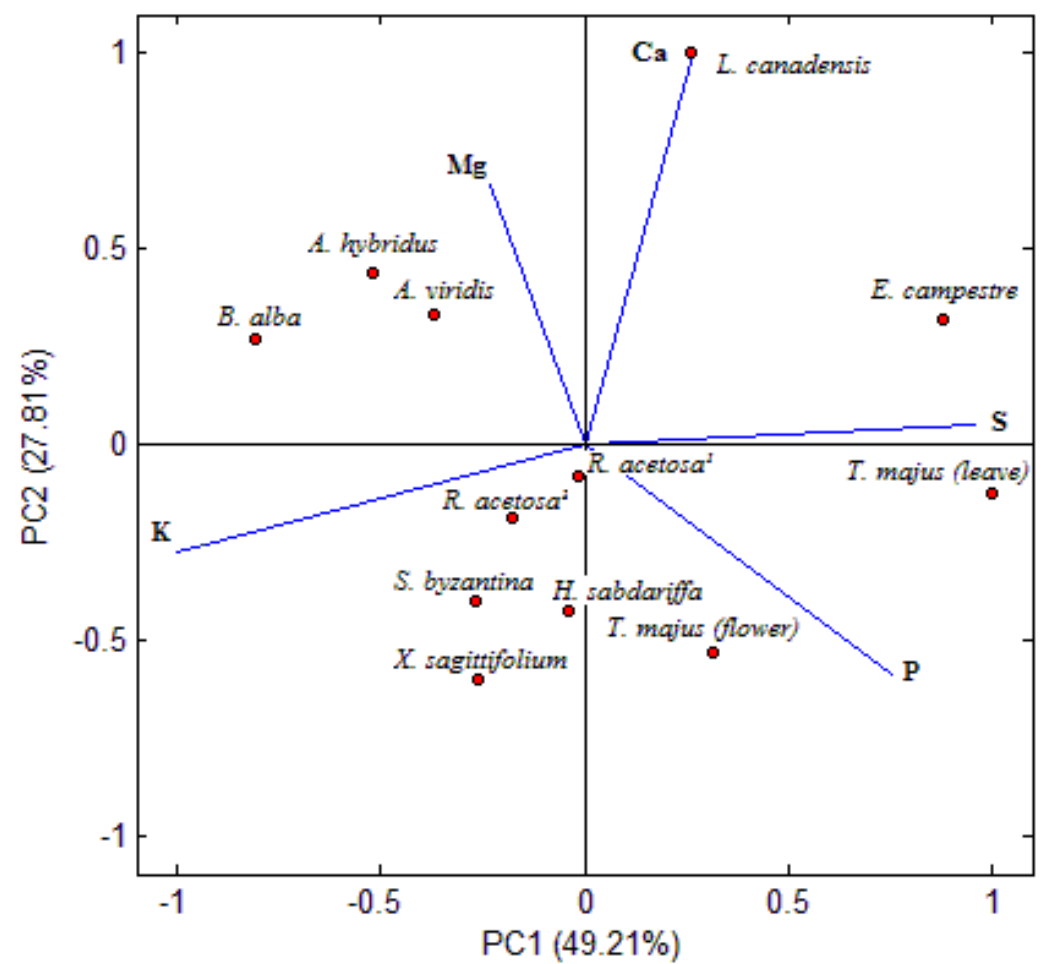

Figure 3 - Analysis of the main components related to the observed results for the levels of macronutrients $\mathrm{P}, \mathrm{K}, \mathrm{Ca}, \mathrm{S}$ and $\mathrm{Mg}$.

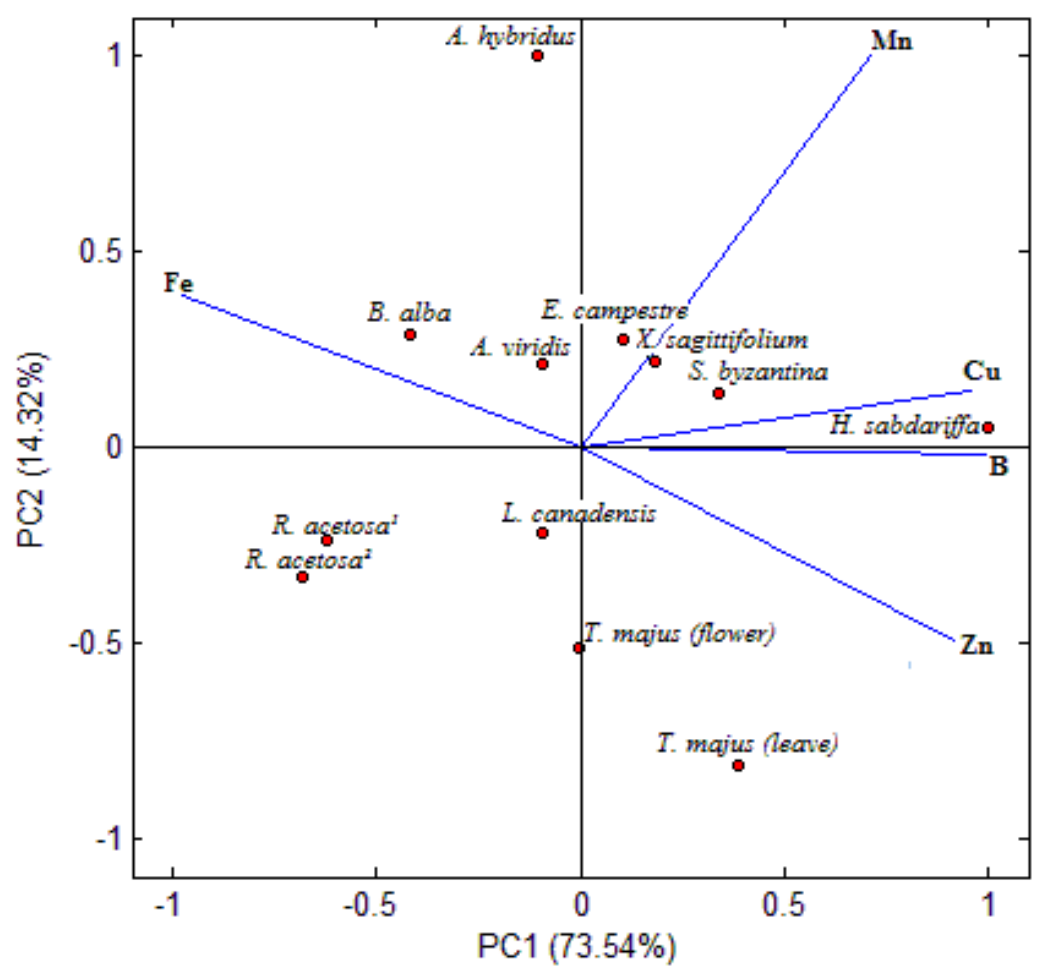

Figure 4 - Analysis of the main components related to the observed results for the constitutions of the species and structures in the micronutrient $\mathrm{Fe}, \mathrm{Cu}, \mathrm{Mn}$, Zn levels. 
average observed level for $\mathrm{S}\left(883 \mathrm{mg} \cdot 100 \mathrm{~g}^{-1}\right)$ it also presented high levels for the minerals $\mathrm{P}$ (525 mg. $100 \mathrm{~g}^{-1}$ ) and $\mathrm{K}\left(1311 \mathrm{mg} \cdot 100 \mathrm{~g}^{-1}\right)$. On the other hand, the species L. canadensis and $H$. sabdariffa presented intermediate values among the evaluated macronutrients, with a highlight to L. canadensis which presented in its constitution the highest observed level for Ca (565 mg. $\left.100 \mathrm{~g}^{-1}\right)$. The remaining two species, $R$. acetos $a^{1,2}$ and $S$. byzantina, presented minimum to intermediate levels for the evaluated macronutrients.

Among the nutrients $\mathrm{Cu}, \mathrm{Fe}, \mathrm{Mn}, \mathrm{Zn}$ and $\mathrm{B}$, the species $R$. acetosa stood out in both evaluated morphological types, mainly because they presented, among their mineral constituents, the highest levels of Fe (average of $592 \mathrm{mg} \cdot \mathrm{kg}^{-1}$ ) and among the highest levels for the other micronutrients evaluated. Regarding the mineral iron, the average value observed in the constitution of all the species and structures evaluated was $21 \mathrm{mg} \cdot 100 \mathrm{~g}^{-1}$, well above the average described for the constitution of conventional hardwoods $\left(0.7 \mathrm{mg} .100 \mathrm{~g}^{-1}\right)$ and a value not only surpassed by that presented in the floral bud of $H$. sabdariffa (0.04 mg. $\left.100 \mathrm{~g}^{-1}\right)$.

L. canadensis species also stood out in relation to the constitution of their micronutrients, mainly because they presented the highest values for $\mathrm{Zn}$ (23.11 mg. $\left.100 \mathrm{~g}^{-1}\right)$, B (5.32 mg. $\left.100 \mathrm{~g}^{-1}\right)$ and $\mathrm{Mn}$ $\left(5.75 \mathrm{mg} .100 \mathrm{~g}^{-1}\right)$. In these same parameters, $T$. majus (flower), $X$. sagittifolium, E. campestre, $A$. viridis, A. bybridus and B. alba species presented intermediate values for these evaluated nutrients, while T. majus (leaves), H. sabdariffa and $S$. byzantina species presented the lowest values for iron and manganese, and intermediate values for the other micronutrients.

\section{DISCUSSION}

The vitamin $\mathrm{C}$ (ascorbic acid) is water soluble and fundamental in the synthesis of collagen, in the tissue repair and in the maintenance of the proper functioning of various sectors of the human metabolism. It also has a role in the immune system, mainly because of its antioxidant properties, since human beings are unable to synthesize ascorbic acid and, as a consequence, need to ingest it through external sources (Lee and Kader 2000, Fuchs 2010). The mean vitamin $C$ level observed in the evaluated species $\left(139.00 \mathrm{mg} .100 \mathrm{~g}^{-1}\right)$ is superior in relation to those observed in the constitution of vegetables commonly used in natura such as salad, lettuce, broccoli, cabbage, cauliflower, spinach, cabbage and arugula which, on average, present $50 \mathrm{mg}$ of this vitamin per $100 \mathrm{~g}$ of the vegetable (Lima 2011). According to the recommendations of FAO/WHO (2001), adults should consume a daily average of $30 \mathrm{mg}$ of this vitamin.

Increasingly scientific importance has been attached to food health. In its normal assignments, human metabolism produces molecules called free radicals, which can react with proteins, lipids, DNA, RNA and other constituents of the organism that can be oxidized. These reactions can cause damage to tissues and organs, often related to degenerative diseases such as cancer. It is suggested the consumption of different biological sources of antioxidant compounds, through the use of products in the food that contains them in their constitution, such as oilseeds, cereals, vegetables (fruits, leaves and tubers), among others, aiming to delay the oxidizing effect and also the appearance of some diseases (Melo et al. 2006). The antioxidant activity in the food is closely related to the presence of components such as phenols, vitamin $\mathrm{C}$, among others, as well as the efficacy of the antioxidant action of these compounds, when ingested, depends on the chemical structure and the rate of their concentrations in each food (Melo et al. 2006).

The antioxidant activity in foods is also generally related to the presence of pigments such as anthocyanins and carotenes (Melo et al. 2006). The anthocyanins observed in the constitution of $H$. sabdariffa are usually responsible for the blue- 
purple color presented by foods, for example, the dark red in the strawberry (Fragaria spp.) (Pinto et al. 2012). These compounds take part in the energy metabolism, through the transformation of carbohydrates and other nutrients into energy and also present some antioxidant properties when ingested, and consequently, a detoxifying effect of the cells (Rocha and Reed 2014) as well as being able to be used as a natural dye in the food industry (Lopes et al. 2007). Among the different species of the genus, $H$. sabdariffa is used in the diet in the form of the consumption of its leaves in natura or of the dried flower buds for the production of jellies or teas (Brasil 2013).

The pectin level observed in its floral bud is significant when compared to other considered species, sources of this compound, that aim at the manufacture of sweets and jellies, such as the guavas (Psidium guajava) from the cultivar Pedro Sato with a total pectin level of $880 \mathrm{mg} .100 \mathrm{~g}^{-1}$ (Linhares et al. 2005) and the strawberries (Fragaria spp.) from the cultivar Sweet Charles (Françoso et al. 2008) with a total pectin level of $750 \mathrm{mg} \cdot 100 \mathrm{~g}^{-1}$. Both values are well below the $1450 \mathrm{mg} \cdot 100 \mathrm{~g}^{-1}$ observed in the constitution of the floral bud of $H$. sabdariffa.

The flowers of H. sabdariffa and T. majus presents high levels when compared to those obtained by Costa et al. (2014), which evaluated these compounds present in passion fruit flowers (90 mg.100 $\mathrm{g}^{-1}$ ), mexican marigold flowers (110 $\left.\mathrm{mg} .100 \mathrm{~g}^{-1}\right)$, red roses and white roses flowers (average of $23 \mathrm{mg} .100 \mathrm{~g}^{-1}$ ) as well as different $T$. majus flowers evaluated (yellow, red and orange) (average of $300 \mathrm{mg} \cdot 100 \mathrm{~g}^{-1}$ ). Carotenoids are natural pigments present in various fruits and vegetables, such as carrots, tomatoes, spinach, oranges and peaches. They are responsible for the appearance of yellow, red and orange color in foods and are classified among the most important compounds from a nutritional point of view. There are different types of carotenoids and, in general, when ingested, they may have a strengthening function of the immune system, reducing the risk of degenerative diseases, and some are precursors of vitamins, which helps maintain the proper functioning of the human body. The anticancer function is also cited for these pigments, due to the antioxidant action, besides being highly important for the final quality of the food (Délia et al. 2008).

Some vegetable species also exhibit antinutritional and oxidant compounds, such as protein inhibitors, calcium oxalates, tannins, nitrates, among others (De Jesus Benevides et al. 2011). In the human body, an excess of nitrates can cause methemoglobinemia (a form of hemoglobin that does not bind to oxygen) besides being carcinogenic and teratogenic. The concentration of this compound in vegetables varies according to climatic conditions and agronomic crop management, as well as post-harvest storage conditions (Van Velzen et al. 2008).

Brazil does not have its own legislation regarding nitrate levels in food. As such, the country follows international law. The European Union sets maximum permitted levels for human consumption where products in excess of these values cannot be marketed. The acceptable daily intake (ADI) established by the Scientific Comitee on Food (SCF) is $3.65 \mathrm{mg} / \mathrm{kg}$ body weight (Eur-Lex 2006). The FAO/WHO establishes an acceptable daily intake of nitrate in human food of $3.7 \mathrm{mg} /$ $\mathrm{kg}$ body weight. According to Van Velzen et al. (2008), about $85 \%$ of the nitrate absorbed in diets comes from vegetables and it is fully absorbed and processed almost completely by the human organism very efficiently regardless whether the vegetables have been cooked or not.

For comparative purposes, assuming the daily dose of $3.7 \mathrm{mg}$ nitrate per kilogram body mass as a limit and considering an adult with a mass of $65 \mathrm{~kg}$, on average, the acceptable daily intake could be a maximum of 135 grams of Amaranthus hybridus or T. majus leaves, species that presented 
higher contents of this antinutritional compound. On average, for the other evaluated structures, the acceptable daily intake could be a maximum of 802 $\mathrm{g}$ for the leaves of E. campestre or $R$. acetosa, and a maximum daily intake of $187.90 \mathrm{~g}$ for the leaves of $A$. viridis or $X$. sagittifolium.

Within the limits elucidated, it would be safe to introduce such vegetables daily into a person's food as regards the nitrate levels obtained here as well as those levels considered acceptable for human consumption. It should be emphasized that there are other compounds considered antinutritional not verified in this work, and there is a clear need for further studies in this sector, until the daily use of these species in human food can be considered totally safe.

In order to meet the needs of human metabolism, the body must acquire from the exogenous environment, through the diet, compounds such as carbohydrates, lipids, proteins, minerals, among others, whose functions, besides structural, serves to supply the metabolic demand (Alberts et al. 2017).

In the literature, there are reports of the use of these two species in natura, sautéed and in drinks and juices in the cuisine of traditional populations (Brasil 2010, 2013). The contained acidity is well regarded to the palate considering juices and drinks, in the case of $R$. acetosa and teas and infusions produced with the floral buds of $H$. sabdariffa.

In the human body, food fibers, among other functions, are important mainly in maintaining the proper functioning of the digestive system. Proteins have structural and metabolic roles, which are essential for the maintenance of living organisms, and the daily recommendation for protein intake by an adult is, on average, 50 grams ( 0.11 pounds).

The two species of Amaranthus evaluated in this work, A. hybridus and A. viridis, especially the latter, stood out among the other species studied because they presented, in their constitutions, the highest levels for protein levels. A. viridis and $A$. hybridus leaves and even most of the intermediate levels obtained for the other species showed crude protein values higher than those commonly found in some leafy vegetables normally marketed and consumed in Brazil, such as the garden lettuce (1300 mg.100g $\left.{ }^{-1}\right)$, the cabbage $\left(2900 \mathrm{mg} \cdot 100 \mathrm{~g}^{-1}\right)$, the spinach (2000 mg.100 $\left.\mathrm{g}^{-1}\right)$ and the arugula (1800 mg. 100g $\mathrm{g}^{-1}$ ) (Lima 2011).

On average, the non-conventional vegetables studied, within the different structures and species, presented the mineral content of $407 \mathrm{mg}$ of $\mathrm{P}$, $1415 \mathrm{mg}$ of K, $192 \mathrm{mg}$ of Ca, $47 \mathrm{mg}$ of $\mathrm{Mg}, 1 \mathrm{mg}$ of $\mathrm{Cu}, 21 \mathrm{mg}$ of $\mathrm{Fe}, 3 \mathrm{mg}$ of $\mathrm{Mn}$ and $10 \mathrm{mg}$ of $\mathrm{Zn}$, all stipulated per $100 \mathrm{~g}$ of each plant sample. Vegetables considered conventional in Brazil such as lettuce, broccoli, kale, cauliflower, mustard and arugula present, on average, the contents of $45 \mathrm{mg}$ of $\mathrm{P}, 331 \mathrm{mg}$ of $\mathrm{K}, 101 \mathrm{mg}$ of $\mathrm{Ca}, 22 \mathrm{mg}$ of $\mathrm{Mg}$, $0.04 \mathrm{Mg}$ of $\mathrm{Cu}, 0.7 \mathrm{mg}$ of $\mathrm{Fe}, 0.35 \mathrm{mg}$ of $\mathrm{Mn}$ and $0.32 \mathrm{mg}$ of $\mathrm{Zn}$, stipulated in $100 \mathrm{~g}$ of the edible part (Lima 2011), values much lower than the averages observed in this study. In order to maintain the proper functioning of the metabolism, the human organism demands to absorb from external sources, through the feeding, different levels of minerals, which are therefore considered essential. The daily recommendations for the ingestion of these minerals vary around the demand of the organism for each element (Eur-Lex 2006).

The results of the nutritional composition of the structures and species analyzed indicate the possible uses for the different purposes presented by the industry and the cooking, suggesting the possibility of using these species as a source of antioxidant compounds and natural pigments in the form of food and for the industry, besides gathering the species evaluated in groups of nutritional similarities. However, for a correct inclusion in the daily diet, further studies are suggested, gauging the maximum recommended portions.

All species studied have varying levels of nutritional compounds of interest. The species $T$. 
majus (garden nasturtium) and A. hybridus (green amaranth) contains the highest observed levels for antioxidant activity.

The species presented vitamin $\mathrm{C}$ in different levels among the analyzed structures, being that the highest levels of this vitamin were observed in the species $X$. sagittifolium (arrowleaf elephant ear), T. majus (garden nasturtium), A. viridis (slender amaranth), $A$. hybridus (green amaranth) and $B$. alba (malabar spinach) as well as when compared to conventional hardwoods.

S. byzantina (lamb's ear) presented the highest observed total phenolic level, as well as lower values for vitamin $\mathrm{C}$ levels, resulting in an intermediate antioxidant activity level.

The species $A$. viridis (slender amaranth), $H$. sabdariffa (roselle), S. byzantina (lamb's ear), $A$. hybridus (green amaranth) and $X$. sagittifolium (arrowleaf elephant ear) presented the highest levels of carbohydrates, lipids, proteins and fibers. H. sabdariffa also stood out for presenting pectin, anthocyanins and carotenoids in their floral buds.

T. majus (garden nasturtium), mainly in its leaf, presented the highest values observed for carbohydrates and caloric value, as well as high levels of proteins, lipids and fibers. This species, in its flowers and leaves, also presented high levels for most of the macronutrients evaluated, and the highest values observed for $\mathrm{S}$. The species $E$. campestre (field eryngo) was also characterized by high levels of macronutrients, mainly $\mathrm{S}$ and $\mathrm{P}$.

$A$. viridis (slender amaranth), X. sagittifolium (arrowleaf elephant ear) and B. alba (malabar spinach) presented high levels of $\mathrm{P}, \mathrm{K}, \mathrm{Ca}, \mathrm{Mg}$ and $\mathrm{S}$. In addition, the species $A$. hybridus and A. viridis, were even more notable for presenting in their leaves the highest levels of proteins, in addition to high levels for all minerals evaluated.

The species $X$. sagittifolium (arrowleaf elephant ear) was also noted for presenting among the highest levels observed for minerals $\mathrm{K}$ and $\mathrm{Cu}$, and the highest level observed for P. The species $L$. canadensis (canada lettuce), in turn, stood out to present the highest levels observed for the minerals $\mathrm{Ca}, \mathrm{Zn}, \mathrm{B}$ and Mn. Both varieties of Rumex acetosa (sorrel) stood out with the higher observed levels of Fe.

On average, the non-conventional vegetables studied presented nutritional levels higher than the averages described for the nutritional constitution of vegetables commonly used in human food.

\section{REFERENCES}

ALBERTS B, BRAY D, HOPKIN K, JOHNSON A, LEWIS J, RARR M, KEITH R AND WALTER P. 2017. Fundamentos da biologia celular. In: Fundamentos da biologia celular. Artmed. Porto Alegre/ Brasil.

ARBOS KA, FREITAS RJSD, STERTZ SC AND DORNAS MF. 2010. Antioxidant activity and phenolic content in organic and conventional vegetables. Ciênc Tecnol Aliment 30: 501-506.

ASNAASHARI S, DELAZAR A, ALIPOUR SS, NAHAR L, WILLIAMS AS, PASDARAN A, MOJARAB M, AZAD FF AND SARKER S. 2010. Chemical composition, freeradical-scavenging and insecticidal activities of the aerial parts of Stachys byzantina. Arch Biol Sci 62: 653-662.

BATISTA MA, PINHEIRO-SANT'ANA HM, CHAVES JBP AND MORAES FA. 2008. Carotenos e provitamina A em bertalha e ervas aromáticas comercializadas em Viçosa, Estado de Minas Gerais, durante as quatro estações do ano. Acta Sci Health Sci 28: 93-100.

BRAND-WILLIAMS W, CUVELIER M AND BERSET C. 1995. Use of a free radical method to evaluate antioxidant activity. LWT-Food Sci Technol 28: 25-30.

BRASIL. 2002. Ministério da Saúde. Secretaria de Políticas de Saúde. Coordenação-Geral da Política de Alimentação e Nutrição. Alimentos regionais brasileiros. Brasília, 141 p.

BRASIL. 2010. Ministério da Agricultura, Pecuária e Abastecimento. Secretaria de Desenvolvimento Agropecuário e Cooperativismo Hortaliças Não Convencionais (Tradicionais). Brasília, 54 p.

BRASIL. 2013. Ministério da Agricultura, Pecuária e Abastecimento. Secretaria de Desenvolvimento Agropecuário e Cooperativismo. Manual de Hortaliças Não Convencionais. Brasília: MAPA/ACS, 99 p.

CATALDO D, MAROON M, SCHRADER L AND YOUNGS V. 1975. Rapid colorimetric determination of nitrate in plant tissue by nitration of salicylic acid 1. Commun Soil Sci Plant Anal 6: 71-80.

COSTA DMA, DE SOUZA MELO HN, FERREIRA SR AND DANTAS JA. 2008. Conteúdo de N, P, $\mathrm{K}^{+}, \mathrm{Ca}^{2+}$ e 
$\mathrm{Mg}^{2+}$ no amaranto (Amaranthus spp.) sob estresse salino e cobertura morta. Rev Cienc Agron 39: 209-216.

COSTA LC, RIBEIRO WS AND BARBOSA JA. 2014. Compostos bioativos e alegações de potencial antioxidante de flores de maracujá, cravo amarelo, rosa e capuchinha. Rev Bras Prod Agroind 16: 279-289.

DE JESUS BENEVIDES CM, SOUZA MV, SOUZA RDB AND LOPES MV. 2011. Fatores antinutricionais em alimentos: revisão. Rev Segurança Alim Nutr 18: 67-79.

DE SOUZA PEREIRA PC, DE FREITAS CF, CHAVES CS, ESTEVÃO BM, PELLOSI DS, TESSARO AL, BATISTELA VR, SCARMINIO IS, CAETANO W AND HIOKA N. 2014. A quimiometria nos cursos de graduação em química: Proposta do uso da análise multivariada na determinação de pka. Quim Nova 37: 1417-1425.

DÉLIA BRA, KIMURA M AND AMAYA-FARFAN J. 2008. Fontes brasileiras de carotenóides: tabela brasileira de composição de carotenoides em alimentos. Brasília: MMA/SBF, $100 \mathrm{p}$.

EMBRAPA. 2006. Transferência de Tecnologia Pantanal - Semi-Árido/Capuchinha. Plantas Medicinais, Condimentares e Aromáticas, 2006. Disponível em: $<$ http://www.campinas.snt.embrapa.br/plantasMedicinais/ capuchinha2.pdf > . Acesso em 5 de Agosto de 2014.

EUR-LEX. 2006. Access to European Union Law. Available at: < http://eur-lex.europa.eu/legal-content/ $\mathrm{PT} / \mathrm{TXT} /$ ?uri=CELEX:32006R1881>. Accessed on September 10, 2014.

FAO/WHO. 2001. Human Vitamin and Mineral Requirements. Report of a Joint FAO/WHO Expert Consultation, Bangkok, Thailand. Food and Nutrition Division, FAO Rome.

FRANÇOSO ILT, COUTO MAL, CANNIATTI-BRAZACA SG AND ARTHUR V. 2008. Alterações físico-químicas em morangos (Fragaria anassa Duch.) irradiados e armazenados. Ciênc Tecnol Aliment 28: 614-619.

FUCHS WL. 2010. Farmacologia Clínica: Fundamentos da Terapêutica Racional. Rio de Janeiro: Guanabara Koogan.

GARZÓN G AND WROLSTAD R. 2009. Major anthocyanins and antioxidant activity of Nasturtium flowers (Tropaeolum majus). Food Chem 114: 44-49.

GIUSTI MM AND WROLSTAD RE. 2001. Characterization and measurement of anthocyanins by UV-visible spectroscopy. Current Protocols in Food Analytical Chemistry. In: Wrolstad RE et al. (Eds), J Wiley \& Sons: New York/ USA, F1.2.1-F1.2.13.

HOROWITZ W. 2016. Official methods of analysis of the Association of Official Analytical Chemists, $20^{\text {th }}$ ed., $3^{\text {rd }}$ rev., Gaithersburg, Maryland: AOAC, 3100 p.

KJELDAHL J. 1983. A new method for the determination of nitrogen in organic matter. Z. Anal Bioanal Chem 22: 366382.
LEE SK AND KADER AA. 2000. Preharvest and postharvest factors influencing vitamin $\mathrm{C}$ content of horticultural crops. Postharvest Biol Technol 20: 207-220.

LIMA DM. 2011. Tabela brasileira de composição de alimentos-TACO. NEPA-UNICAMP, $164 \mathrm{p}$.

LINHARES LA, SANTOS CDD, ABREU CMPD AND CORRÊA AD. 2005. Transformações químicas, físicas e enzimáticas de goiabas 'Pedro Sato' tratadas na póscolheita com cloreto de cálcio e 1-metilciclopropeno. Ciênc Agrotec 31: 829-841.

LOPES T, XAVIER M, QUADRI MG AND QUADRI M. 2007. Antocianinas: uma breve revisão das características estruturais e da estabilidade. Rev Bras Agrocienc 13: 291 297.

LU TJ, CHEN JC, LIN C AND CHANG YH. 2005. Properties of starches from cocoyam (Xanthosoma sagittifolium) tubers planted in different seasons. Food Chem 91: 69-77.

MCCREADY P AND MCCOMB E. 1952. Extraction and determination of total pectin materials. Anal Chem 24: 1586-1590.

MELO EDA, MACIEL MIS, LIMA VLAG, LEAL FLL, CAETANO ACDS AND NASCIMENTO RJ. 2006. Capacidade antioxidante de hortaliças usualmente consumidas. Ciênc Tecnol Aliment 26: 639-644.

MLCEK J AND ROP O. 2011. Fresh edible flowers of ornamental plants-A new source of nutraceutical foods. Trends Food Sci Technol 22: 561-569.

NDABIKUNZE B, TALWANA H, MONGI R, ISSAZACHARIA A, SEREM A, PALAPALA V AND NANDI J. 2011. Proximate and mineral composition of cocoyam (Colocasia esculenta L. and Xanthosoma sagittifolium L.) grown along the Lake Victoria Basin in Tanzania and Uganda. Afr J Food Sci 5: 248-254.

NIIZU P AND RODRIGUEZ-AMAYA DB. 2005. Flowers and leaves of Tropaeolum majus L. as rich sources of lutein. J Food Sci 70: 605-609.

OLIVEIRA DDCS, WOBETO C, ZANUZO MR AND SEVERGNINI C. 2013. Composição mineral e teor de ácido ascórbico nas folhas de quatro espécies olerícolas não-convencionais. Hortic Bras 31: 472-475.

OSBORNE D AND VOOGT P. 1978. The analysis of nutrients in foods. Academic Press Inc. (London) Ltd., 24/28 Oval Road, London NW1 7DX.

PINTO AG, SILVA LFLE, CARMINATTI R, MORALES RGF AND SARMIENTO CM. 2012. Análise físico-química de frutos de sete cultivares de morangueiro. In: Congresso de Pós-Graduação da UFLA. 21..., Anais... Lavras, 2012.

ROCHA DS AND REED E. 2014. Pigmentos Naturais em Alimentos e sua Importância para a Saúde. Rev Estud 41: 76-85.

RODRIGUEZ-AMAYA DB, RAYMUNDO LC, LEE TC, SIMPSON KL AND CHICHESTER CO. 1976. 
Carotenoid pigment changes in ripening Momordica charantia fruits. Ann Bot 40: 615-624.

RODRÍGUEZ L, LOPEZ DJ, PRESTON T AND PETERS K. 2006. New Cocoyam (Xanthosoma sagittifolium) leaves as partial replacement for soybean meal in sugar cane juice diets for growing pigs. Livestock Res Rural Dev, vol. 18.

RUFINO M, ALVES RE, DE BRITO ES, DE MORAIS SM, SAMPAIO CDG, PÉREZ-JIMENEZ J AND SAURA-CALIXTO FD. 2007. Metodologia científica: determinação da atividade antioxidante total em frutas pela captura do radical livre $\mathrm{ABTS}^{\circ}+$. Embrapa Agroindústria Tropical. Comunicado Técnico.

SILVA ECDA, CARLOS LDA, ARAÚJO AP, FERRAZ LDC, PEDROSA MW AND SILVA LS. 2013. Characterization of two types of azedinha in the region of Sete Lagoas, Brazil. Hortic Bras 31: 328-331.
SILVA FC. 2009. Manual de análises químicas de solos, plantas e fertilizantes, $2^{\mathrm{a}}$ ed., Brasília: Embrapa Informação Tecnológica, $627 \mathrm{p}$.

SINGLETON VL AND ROSSI JA. 1965. Colorimetry of total phenolics with phosphomolybdic-phosphotungstic acid reagents. Am J Enology Vitic 16: 144-158.

SOUZA LS, VELINI ED, MAIMONI-RODELLA R AND MARTINS D. 1999. Contents of macronutrients and micronutrients and $\mathrm{CN}$ relation of several weed species. Planta Daninha 17: 163-167.

VAN VELZEN AG, SIPS AJ, SCHOTHORST RC, LAMBERS AC AND MEULENBELT J. 2008. The oral bioavailability of nitrate from nitrate-rich vegetables in humans. Toxicol Lett 181: 177-181. 